Article

\title{
Core Firm Based View on the Mechanism of Constructing an Enterprise Innovation Ecosystem: A Case Study of Haier Group
}

\author{
Shimei Jiang ${ }^{1}$, Yimei $\mathrm{Hu}^{2, *}$ (D) and Ziyuan Wang ${ }^{3}$ \\ 1 School of Economics and Management, Hebei University of Technology, Tianjin 0401, China; \\ jiangshim@163.com \\ 2 Department of Business and Management, Aalborg University, 9200 Aalborg East, Denmark \\ 3 Beijing Foton Daimler Automotive Co., Ltd., Beijing 101400, China; wangziyuan@bfda.cn \\ * Correspondence: yimei@business.aau.dk; Tel.: +45-9940-8360
}

Received: 2 May 2019; Accepted: 26 May 2019; Published: 1 June 2019 updates

\begin{abstract}
The fierce competitive status of the business world has urged innovation activities to transform from mechanistic to ecological and organic. An innovation ecosystem consists of multilateral organizations and emerges as a favorable mechanism for value co-creation and sustainable growth. Yet the theorizing of an innovation ecosystem is still at an early stage and in-depth studies from emerging economy leaders are insufficient. This study aims to investigate how an innovation ecosystem is constructed and coordinated from a core-firm based view. An exploratory single case study on the Haier Group is adopted. Through analyzing the multi-bedded units (i.e., six innovation projects/technological breakthroughs), we extract and depict Haier's innovation ecosystem and the ecological niches within it. We highlight an innovation ecosystem that promotes sustainable development and is based on complementarities in technologies and resources, while at the same time integrates non-technological issues such as strategy, culture, institution, and the market. Regarding ecosystem coordination, value appropriability should be ensured to sustain the innovation ecosystem. Moreover, we argue that the ultimate purpose of innovation ecosystem is not to facilitate the realization of one specific project, but rather to improve the overall success rate of innovations within it. This research complements and extends literature on enterprise innovation ecosystems, and provides implications as to the construction, coordination, and sustainability of innovation ecosystems for emerging economy firms.
\end{abstract}

Keywords: innovation ecosystem; core firm; sustainability; open innovation; innovation network

\section{Introduction}

Innovation, as a key driver for achieving sustainability, has been widely recognized [1,2]. Unlike traditional innovation activities which pursue economic value through profit maximization, sustainable innovation balances ethical, long-term oriented, societal, and ecological principles associated with development, and therefore promotes environmental, social, and economic values for individuals, organizations, and nations [3-5]. Due to the increasing uncertainties associated with the fast-changing business environment and complexity of tasks, close innovation and do-it-alone mentality can hardly cope with the fierce business competition and sustainable development requirements nowadays. Therefore the innovation ecosystem, which refers to an alignment structure in which multilateral partners interact to realize a focal value proposition [6], has emerged as a popular and effective arrangement to coordinate innovation activities. Within an innovation ecosystem, various innovation actors holding complementary resources and capabilities dynamically interact with each other and work 
together in a loosely coupled manner. The interdependency and symbiosis between ecosystem actors ensure the survival, balance, continuous renewal, and sustainable development of the ecosystem $[7,8]$. As representative regional innovation ecosystems, Silicon Valley and Zhongguancun have significantly promoted the technological innovation and economic development of the U.S. and China, respectively. At the corporate level, industrial leaders such as Haier, Alibaba, Apple, Microsoft, and Huawei, through establishing enterprise innovation ecosystems and continuously supporting entrepreneurial initiatives, have not only facilitated the spring-up of new, disruptive technologies and products creating value to consumers and sustainable development for societies, but also achieved sustainable business growth and competitive advantages.

The construction and coordination of innovation ecosystem has been a popular topic in recent years and has gained the attention of business managers, academic researchers, and policymakers. There have been quite a few researches on innovation ecosystem from research angles such as innovation networks, industrial platforms, technological interdependence, and business models $[3,9,10]$. However, the concept of innovation ecosystem remains highly debatable [11], and the theorizing of the innovation ecosystem concept, construction, and coordination is still at an early stage [8]. Further, innovation ecosystem researches focusing on the emerging economy such as China, especially in-depth case studies sharing experiences of innovation ecosystem construction and coordination by Chinese industrial leaders from both technological and non-technological dimensions, remain are scant [12]. Therefore, carrying out case studies grounded in the Chinese context is urgently needed to provide both theoretical and practical insights.

This study aims to investigate the following questions: (1) How does a core firm construct an enterprise innovation ecosystem to gain sustainable development? (2) How does a core firm coordinate its relationships with innovation ecosystem actors to gain sustainable development? An exploratory single case study design is adopted to investigates the construction and coordination of an enterprise innovation ecosystem from a core firm's perspective. The chosen case, Haier Group, is the world leading provider in white home appliance, and owns well-known brands such as Haier, Casarte, GE Appliances, Fisher \& Paykel, etc. Alongside the Haier Group's business success and sustainable competitive advantages, its unique organizational design, innovation platform and strategy, and continuous entrepreneurial vitality may also shed light on how emerging economy businesses and innovation actors cope with challenges arising from the era of open innovation and internet of things and gain sustainable development [13]. Up to date, the Haier Group has established five research and development (R\&D) centers, globally connecting and leveraging global innovation resources and talents, and its innovation ecosystem has become the largest open innovation community and resource allocation platform in China and even Asia.

The study unfolds Haier's experiences of constructing and coordinating innovation ecosystem for continuous and sustainable innovation and development and contributes existing literature on innovation ecosystem by proposing frameworks that depict Haier's innovation ecosystem and highlight both technological and non-technological issues. Moreover, the study enriches our understandings on the innovation management experiences of global leaders from China, which provide managerial implications for business practitioners.

The rest of the paper is organized as follows: Section 2 reviews literature regarding the concept of innovation ecosystem, how it relates to sustainability issues, and key components and management of innovation ecosystems; Section 3 introduces the case study method of this study, which is followed by Section 4 which presents the case findings and analysis; Section 5 summarizes the research findings, highlights the contributions and implications, and discusses future research possibilities.

\section{Literature Review}

\subsection{Innovation Ecosystem and Sustainability}

Informed by the natural biological ecosystems, scholars first proposed the business ecosystem concept in the 1990s [14], and since then the ecosystem metaphor has been widely adopted in recent 
strategic management and innovation management literature $[7,8,15,16]$. An business ecosystem can be defined as the alignment structure between multilateral actors that interact to realize a focal value proposition [6]. Similar to species and populations, no business organizations can survive alone, and are inevitably involved in resource exchanges and interactions with other organizations directly or indirectly in complex and non-linear ways. Ecosystem actors hold their ecological niche (i.e., the position within the ecosystem), which are interdependent and symbiotic, and achieve the balance and sustainability of the whole system. Traditional hierarchical organizations exert intensive control over individuals and business units within it, which may harm innovation potential and eventually lead to organizational rigidity and inefficiency. In contrast to that, actors within a business ecosystem interact in a flexible, networked, and loosely-coupled manner, which enables the flow of complementary resources and knowledge across organizational boundaries, and hence allows learning and incubates new ideas and innovation potential. Within an ecosystem, actors' (individuals and firms) activities and behaviors are mutually impacted and shaped by the networks and contexts they are embedded in [17], and thus ecosystem actors are co-evolving and continuously adapting to the environment to survive and gain sustainable development.

The appearance of terms such as "ecosystem", "innovation ecosystem", and "business ecosystem" in academic researches and industrial reports has progressively increased in recent years. However, some scholars question the credibility of the "ecosystem" term, and argue it is nothing new compared to terms such as "innovation networks" and "innovation systems" [11]. Facing the criticisms, some other scholars have tried to defend "innovation ecosystem" and theorizing about the ecosystem is one of the primary tasks in strategic and innovation management literature $[7,8,18]$.

A network consists of nodes (actors) and ties (relationships), and an innovation network depicts the interconnected relationships between collaborative innovators. As a very broad term, an innovation network can be very hierarchical (i.e., a hierarchical network with a leading actor controlling the others). Moreover, some scholars hold a network perspective that conceptualizes all organizations, including an arm's length market, as networks [19]. Researches on innovation networks mainly focus on the structural features and take for granted that actors work seamlessly and collaboratively. The term "innovation system" has existed for more than two decades and is usually used in national or regional innovation system contexts. Unlike the structure focus of innovation network researches, innovation system literature emphasizes the top-down regulatory and stimulating influences exerted by governments and institutions, and holds a static view [2].

What differs between the innovation ecosystem and innovation networks and innovation systems is the "ecological" characteristics $[7,14]$. Innovation networks usually focus on how partners can work collaboratively in specific projects, and innovation system studies emphasize how governmental policies can promote those targeted star enterprises or regions. Unlike the deterministic approach, the innovation ecosystem can be seen as a rainforest within which actors interact cooperatively and competitively. The innovation ecosystem shows a shift in mindsets (i.e., the ultimate purpose of an innovation ecosystem is not to ensure the success of one or several specific firms or projects, but to enhance the overall success rate within the ecosystem) [20]. The improvement of the overall success rate ensures the sustainable innovation potential and vitality, and we hereby specifically argue that sustainability is an essential component of the innovation ecosystem.

First, innovation facilitates the sustainability of an ecosystem. Unlike innovation networks or innovation systems that take a static view, the innovation ecosystem evolves to adapt to the changing business and institutional environments in order to survive and sustain. As mentioned earlier, the prosperous and dynamic knowledge and resources flow between actors within an ecosystem and cultivate new ideas to realized economical, societal, or ecological values (i.e., innovations). Innovations emerge from an ecosystem can be seen as mutations or breakthroughs, which may temporarily alter the balance between symbiotic actors and the status quo. Such mutations may lead the ecosystem to various possible evolutionary directions. However, only those that fit the market or business environments can be selected and retained. The retained innovations thus in return shape the ecosystem 
to sustain, gain competitive advantages, and evolve through four stages: birth, expansion, leadership, and self-renewal [14,21]. Through continuous innovation, an ecosystem itself can achieve sustainability [2].

Second, a sustainable innovation ecosystem stimulates innovation continuously and facilitates the increasing sustainability appeals. Innovation refers to the whole value-creating process from idea generation to idea conversion and idea diffusion [22]. Due to the increasing complexity of production processes, rapid changing demands, and shortened business life cycles, fulfilling the increasing sustainability appeals pursuing balanced development between economical, societal and ecological aspects, is beyond individual capacity. Therefore, the ecosystem emerges as an effective and efficient mechanism to integrate capabilities, resources and efforts from various partners, and facilitates the whole innovation process from ideation to value realization. The evolution and renewal of an ecosystem may also incubate more innovations, and only those with sustainable subjects or long-term oriented value creation merits can be selected; hence an ecosystem continuously creates value for the sustainable and benign development of the economy and society $[2,4,17]$. That is to say, an ecosystem on the one hand enables the fulfillment of sustainability requirements, and on the other hand, the sustainable innovation process is essential to the existence and sustainability of an innovation ecosystem [2].

Third, an innovation ecosystem facilitates sustainable development and competitive advantages. Regarding firms within an innovation ecosystem, only a sustainable ecosystem can continuously maintain innovation incentives and facilitate the benign interactions among symbiotic partners, and provide opportunities for them to co-create value through continuous innovative offerings $[6,23]$. Through continuous innovative offerings and value creation, competitive advantages can be gained not only at the individual level, but also at the relational or network level [24-26].

In summary, though the innovation ecosystem has a network structure and system feature, it has its specific emphasis on evolution and is closely related to sustainability. Innovations on sustainability issues improve social welfare and economic growth, and also stimulate the evolution and sustainability of an ecosystem; while vice versa, a sustainable ecosystem stimulates innovations that add value to the sustainability of an economy and society, and facilitates the sustaining of firms' competitive advantages. In recent years, the innovation ecosystem perspective has been adopted in studying the innovation strategies and management in Chinese firms and industries. These researches usually focus on discussing how an innovation ecosystem evolves from birth to expansion to renewal, how technological innovation is achieved and upgraded alongside the ecosystem evolution [12], and the driving forces of sustaining an innovation ecosystem [21]. Yet, the "eco" nature of innovation ecosystem studies is often criticized to be taken for granted or ignored [11]. Studies on how different actors are aligned in a symbiotic way and how ecological niches are formed within an innovation ecosystem remain at the conceptual and early stage [27], and in-depth empirical studies are highly insufficient. Moreover, though interdependence and complementarity between different technologies are an inherent feature of an innovation ecosystem, the performance and sustainability of the innovation ecosystem relies not only on technological issues, but also on non-technological issues, which also calls for more investigation.

\subsection{Core Firm and Enterprise Innovation Ecosystem}

An innovation ecosystem can emerge at the regional level, which enhances regional competences and sustainable development though continuous innovation and entrepreneurial attempts (e.g., Silicon Valley). The emergence of Silicon Valley is due to complex or even random reasons such as alumni networks, an open culture that encourages innovation, and active venture capitalists [20], and therefore it is difficult to replicate its success. In contrast to regional innovation ecosystems, more and more studies focus on how firms can align strategically or purposefully to construct innovation ecosystems to co-create values while ensuring the appropriation of value in order to gain business sustainability $[12,15,27,28]$.

As the construction and evolution of an enterprise innovation ecosystem usually involves one or more core firms that act as leaders and facilitators, the role of core firms are especially essential under high uncertainty and ambiguity [28]. Core firms utilize their unique competitive advantages to develop 
and expand themselves within an ecosystem, and initiate multi-level collaborative relationships between ecosystem actors, which are essential to the survival and evolution of the ecosystem. Yet, the definition of core firms remains ambiguous and debatable in existing literature, and it is usually used interchangeably with concepts such as hub firm, flagship firm, leading firm, and focal firm [12,29]. It is also worth noting that having a core firm holding a leadership role does not mean the enterprise ecosystem will fall into a centralized and stabilized mode, which deviates from the evolutionary requirements and impedes innovation potential. Rather, a core firm can maneuver and orchestrate resources and various actors, and strategically facilitates the formation of an adaptive ecosystem that continuously creates value and cultivates innovation [18].

Scholars usually define a core firm's missions and tasks based on the following main dimensions: position, resource endowment and competence, coordination capabilities, and leadership. A core firm is usually located at a central or core position within an ecosystem [29,30]; is capable of constructing and sustaining an ecosystem while sharing and integrating innovation resources within the network [31]; enables a mechanism that selects and decides the entry and exist of ecosystem actors [12]; processes essential and unique technology or resources [32]; provides a platform that bridges various actors, facilitates knowledge flow, and forges partnerships [33,34]; accelerates innovation processes [16,23]; inspires encouraging entrepreneurship [35]; facilitates the value realization and final launch of new products or services [36], and ensures value appropriability among ecosystem actors [24]. Studies on enterprise innovation ecosystem can be identified and analyzed from perspectives with different focuses. Some scholars focus on how innovation actors are connected by technological innovations to an organic structure [2,30]. Some emphasize the complementarities, technological interdependence, modularity of tasks, and structure among actors [8,15,37], while others highlight the evolutionary nature of innovation ecosystems and how the ecosystem adopts and interacts with institutional environments [14]. Recently, some scholars have raised the issue of coopetition within an ecosystem (i.e., ecosystem actors cooperative with each other to co-create value, while simultaneously compete on value appropriation) [32,38]. Yet, there lacks a core-firm based and synthesized perspective, which investigates how an innovation ecosystem is strategically constructed and coordinated from not only from a technological dimension, but also from other non-technological innovation management dimensions [39].

\subsection{Enterprise Innovation Ecosystem Coordination and Sustainability}

An innovation ecosystem forges partnerships and cooperation. Yet unlike most of the innovation network literature that tries to avoid competition between partners, and takes for granted a trustful and win-win relationship, the innovation ecosystem by nature incorporates both cooperation and competition [40]. On the one hand, partners cooperate to co-create value within an innovation ecosystem; while on the other hand they compete for individual value appropriation. Instead of regarding cooperation and competition as an either/or choice (i.e., avoiding competition between partners), more and more scholars recognize that the co-existence of cooperation and competition (i.e., coopetition), is inevitable in partnerships and ecosystems [41,42]. Fierce competition and opportunistic behaviors will harm the value co-creation purpose and may eventually deteriorate the ecosystem [43], while a balance between cooperation and competition can facilitate ecosystem performance and its sustainable development $[32,44]$. Thus, how to coordinate and balance the tensions between ecosystem partners are of extreme importance to the sustainability of the whole ecosystem. Ecosystem coordination and the relationship between ecosystem actors can be investigated from the following dimensions: cooperation motives, ecosystem principles, value co-creation and appropriation mechanisms, and ecosystem conflict management.

- Cooperation motives:

It has become a common understanding that under highly uncertain, competitive, and dynamic business environments, no single firm can fulfill the whole value adding process of a technological 
innovation. As discussed above, sustainability in various aspects is becoming an increasing pursuit, and requires combined efforts. Driven by the value co-creation motive, partnering with suppliers, customers, research institutes, industrial intermediaries, and even rivals, becomes a necessity in terms of realizing innovations and common value propositions $[6,45]$. This is also in line with the open innovation paradigm [46].

- Ecosystem principles:

The principle and underlying rationale of cooperation between ecosystem partners are based on complementarities between technology, resources, and capabilities held by different ecosystem actors, which optimize value co-creation synergy. Yet, besides complementarity and value co-creation, another highly neglected principle is the value appropriability and reciprocity $[29,47]$. A third precondition that allows the formation of an ecosystem is modularity [8], which allows distinct and geographically distant, while interdependent innovations, to work jointly without a hierarchical structure.

- Value co-creation mechanism:

Constructing an ecosystem requires various mechanisms depending on the type of the core firm and partners, and their relationships $[18,28,47]$. Some scholars argue the importance of establishing a knowledge sharing mechanism $[24,27]$ in value co-creation. An innovation platform can therefore serve as a knowledge sharing mechanism. In many cases, an ecosystem core firm can also be the provider of an innovation platform. According to Gawer and Cusumano [23], an internal or company-specific platform organizes a set of organizational assets in a common structure from which the focal organization can effectively and efficiently accomplish a series of innovation projects. While due to the popularity of the open innovation trend, more and more external enterprise platforms emerge. These platforms provide a stage for knowledge, resources, and technologies to flow across organizational boundaries, and bridge various innovators to form an ecosystem to generate a large number of innovations.

- Ecosystem conflict management:

As aforementioned, ecosystem actors simultaneously cooperate and compete with each other, (i.e., coopetition). Fierce competition may delude the value co-creation purpose, and even erode the innovation ecosystem [41]. Hence a core issue is to manage the conflicts among actors. Scholars have proposed various solutions, such as facilitating co-learning and establishing a common governance [25,29], ensuring the network stability and individual actor's value appropriability $[29,38]$, figuring out an ecosystem vision and facilitating a benign culture [28], and balancing the cooperative initiatives on value co-creation and competitive aims on individual value appropriation [32].

A core firm performs a leadership role in the establishment of an enterprise innovation ecosystem and selection of partners. Existing researches have summarized various innovation ecosystem coordination methods and mechanisms based on different perspectives. Yet these researches usually regard the ecosystem as a holistic structure with individual firms embedded in as nodes, or take a project or technology upgrading as the focus and see how various actors are aligned around the specific task [12,21]. Few take a core-firm based view and consider how it constructs an enterprise innovation ecosystem, and coordinates the ecosystem considering both technological and non-technological aspects [28]. Specifically, in-depth case studies from emerging economy industrial leaders' perspectives providing detailed insights are insufficient.

\section{Method}

We adopted a single case research design, and the Haier Group, the world's leading brand and industrial forerunner of major appliances, was chosen as our exploratory case. As the whole Haier Group is multinational and has an open boundary that is impossible to capture every detailed aspect of it, we applied a multi-embedded case study design and investigated six disruptive innovation products/technologies released in recent years by the Haier Group, which can provide us with a 
generalized picture of Haier's enterprise ecosystem and the symbiotic relationships between ecosystem actors. Through exploring the ecological niche of the enterprise innovation ecosystem and the coordination of ecosystem actors from a core-firm based view, we aim to propose a framework depicting a core-firm based innovation ecosystem which extends existing literature on innovation ecosystems and enriches our understandings on Chinese firms' practices.

\subsection{Case Study Method and the Haier Group}

Firstly, this research tries to explore the mechanisms of "how" a core firm constructs an enterprise innovation ecosystem, as well as key components of it. A case study design which starts with contextual rich practical and managerial issues and explores interesting phenomenon that current theories can hardly describe and explain is a suitable design [48]. Secondly, analyzing unique or representative cases, especially exploratory case studies, can break through current theoretical paradigms, utilize new perspectives, presumptions, and approaches to investigate social-economic phenomenon, which may sharpen and extend existing theories by identifying research gaps and filling them. Lastly, this study adopts a multi-embedded design, which is in line with the replication principle which improves the validity and reliability of the research. Rather than statistical sampling, this case study adopts a theoretical sampling principle [48], and aims to replicate a unique type or representative case to extend the existing theory and generalize to other cases. Hence the case selection principle is whether the case is suitable to answer the research problem and whether it fits the contextual setting of the research problem.

Founded in 1984, the Haier Group has transformed from a collective small factory on the verge of bankruptcy, to a world leader in the home appliance industry featured by its open boundaries, ecological organization, and innovation ecosystem that integrates global industrial innovation resources and talents. In the past nine consecutive years, Haier has achieved a yearly profit increase of $10 \%$. In 2018, Haier's ecosystem revenue reached 15.1 billion RMB, increased by $75 \%$ compared to the previous year. Currently Haier has 10 R\&D centers, 24 industrial parks, and has established global manufacturing plants. (Haier Group's official websites: http://www.haier.net/en/about_haier/ (accessed on May 2019)).

Haier started to design a unique mode called "win-win between person and order" in 2005. In the year of 2010, Haier initiated a "self-operating unit" globally, and further announced the network strategy in 2012. In the past few years, Haier has creatively constructed an innovation ecosystem around itself, integrating resources based on pinpointing pain points of consumers, and thus continuously improving the innovation performance and sustainability of the whole ecosystem. As a core firm, Haier not only constructed a global interactive innovation ecosystem, but also creatively initiated the "self-operating unit" managerial mode based on the global business environment and its own business appeals, and cultivated an innovative corporate culture to coordinate the complex networking and non-linear innovation ecosystem.

As Haier' group and innovation ecosystem is enormous and complex, in order to figure out how the ecosystem functions and the underlying rationale, a multi-embedded case study design can help us to understand the multifaceted complex ecosystem through investigating in detail its sub-units. The sub-unit analysis can be then further generalized to understand the chosen case (i.e., the Haier Group) in this study. A multi-embedded case study design requires that each analytical unit suits the context the research problem sets. The breakthrough innovation products/technology developed and released by Haier in recent years covers a complete innovation process, involves various firms with different competences, and can answer the research questions in a comprehensive way. Moreover, the six analytical units (i.e., six innovation projects), are all incubated from Haier's innovation platform called HOPE (The Haier Open Partnership Ecosystem), which corresponds to the declaration of "the entire globe is your R\&D department" proposed by the CEO of Haier, Mr. Zhang Ruimin.

The Haier Group's success in constructing and coordinating an enterprise innovation ecosystem is unique and representative in the traditional manufacturing sector. Being a representative and 
insightful case, Haier's innovation management experiences not only reflect the Chinese context and represent the frontier of Chinese style management, but also are well-recognized all over the world. For instance, at Harvard Business Publishing, there have been 30 case studies since the 1990s on the Haier Group from aspects such as: Haier's internationalization strategy; Haier's international marketing and branding strategies in Japan, India and the U.S.; Haier's acquisition of famous brands such as GE; and Haier's corporate entrepreneurship in 2018. In September 2018, Haier proposed its "3E" model which fits the IoT (Internet of Things) era for sustainable innovation and development, which refers to ecosystem, eco-revenue, and eco-brand. Yet, in-depth researches unfolding Haier's innovation ecosystem is at an early stage. Therefore, this in-depth case study on the Haier Group's enterprise innovation ecosystem is timely and can be seen as an valuable opportunity, which adds to knowledge on Chinese firms' innovation strategies and ecosystem coordination, and has the potential of extending the existing literature.

\subsection{Data Collection}

We collected data from various sources such as company interviews, documents, archives, direct observations, and participatory observations. In terms of primary data collection, we adopted the pyramidal design and selected multi-level key informants (i.e., from higher executives, department managers, and junior employees). The interviews and discussions covered various aspects such as the corporate and department strategy of Haier, internal regulations and rules, corporate culture, technologies, and markets. Secondary data such as documents and archives, including the internal newspaper called Haier Weekly, meeting records, media interviews, and published articles, were also collected. Based on the multi-embedded case study design, we focused on the research and design phase of product/technological innovations developed and released in recent years, and tried to investigate the construction mechanism, key components, and management of Haier's enterprise innovation ecosystem.

Semi-structured interviews are the most important data source of this research. Informed by our literature review, we developed themes and questions regarding innovation and technological development processes [22], and ecosystem coordination themes are shown in Section 2.3. Also based on the identified gaps, we asked questions related to the non-technological side of an innovation ecosystem, for instance. However, due to the exploratory nature of this study, the aim was theory extending, hence we allowed the informants to reflect on the facts of the case and at the same time elaborate their own insights, which helped to find new insights and extend current understandings. Two rounds of interviews were carried out. At the first round, we conducted three trial semi-structured interviews with staff working at the Haier open innovation center, aiming to confirm and delimitate our research questions, get first answers to the research questions, as well as prepare for the next round of interviews. The second-round interviews included six structured or semi-structured interviews with project managers and key account managers coordinating R\&D partners, which gave us detailed and specific information on the research and design process of the six disruptive innovation products. Interviewees provided information covering the following themes: sources of innovation ideas, selection of technological partners, the initiation of collaborations, coordination during the collaboration, maintenance of later relationships, development and services of new products, etc. The second-round interviews gave us an overview of the six innovations which allowed us to fulfill our research objective of theory building. Table 1 provides an overview on the interviews. 
Table 1. Interview overview.

\begin{tabular}{|c|c|c|c|c|}
\hline Interview Round & Interviewee & Department & Project in Charge & Duration \\
\hline \multirow{3}{*}{ First Round } & General manager & $\begin{array}{l}\text { Innovation and } \\
\text { Resource Center }\end{array}$ & Link resources & $35 \mathrm{~min}$ \\
\hline & Director & $\begin{array}{l}\text { Innovation and } \\
\text { Resource Center }\end{array}$ & $\begin{array}{l}\text { Link resources; } \\
\text { Platform operation }\end{array}$ & $45 \mathrm{~min}$ \\
\hline & Manager & $\begin{array}{l}\text { Innovation and } \\
\text { Resource Center }\end{array}$ & $\begin{array}{l}\text { Link resources; } \\
\text { Platform operation }\end{array}$ & $165 \mathrm{~min}$ \\
\hline \multirow{6}{*}{ Second Round } & Minister A & $\begin{array}{l}\text { Innovation and } \\
\text { Resource Center }\end{array}$ & NOCO water heater & $40 \min$ \\
\hline & Engineer A & $\begin{array}{l}\text { Innovation and } \\
\text { Resource Center }\end{array}$ & $\begin{array}{c}\text { Tianzun air } \\
\text { conditioningsystem }\end{array}$ & $35 \mathrm{~min}$ \\
\hline & Engineer B & $\begin{array}{l}\text { Innovation and } \\
\text { Resource Center }\end{array}$ & $\begin{array}{l}\text { Energy storage water } \\
\text { heater }\end{array}$ & $55 \mathrm{~min}$ \\
\hline & Doctor & Advanced R\&D Center & Solid state refrigeration & $80 \mathrm{~min}$ \\
\hline & Engineer $\mathrm{C}$ & Advanced R\&D Center & $\begin{array}{c}\text { Xingchu refrigerator } \\
\text { Tianzun air }\end{array}$ & $40 \mathrm{~min}$ \\
\hline & Minister B & Advanced R\&D Center & $\begin{array}{l}\text { conditioning system; } \\
\text { magnetic refrigerator }\end{array}$ & $70 \mathrm{~min}$ \\
\hline
\end{tabular}

\subsection{Data Analysis}

As this study is exploratory in nature, a typical coding process was followed [49]. We firstly categorized the collected primary and secondary data according to data sources and sub-cases, and then open coded all the data into conceptual nodes (See Table 2). Letters and numbers within Table 2 represent types of data sources. For example, A2 represents semi-structured interview transcripts discussing energy storing water heater project. After primary coding, we conducted second-round coding, grouping the nodes related to theoretical constructs that were related to existing researches. The theoretical constructs were identified based on major issues of innovation projects and the key value realization nodes alongside the innovation value adding processes from existing literature (i.e., from idea generation, to conversion and diffusion) [22]. Then we looked into the underlying logic and relationships between theoretical constructs and aimed to propose new theoretical frameworks. After following the replication principle and several rounds of reflecting back and forth between practice and the proposed theoretical model, we finally summarized our research findings.

Table 2. Coding and data classification based on sub-cases.

\begin{tabular}{|c|c|c|c|c|c|c|}
\hline \multirow{2}{*}{ Data Classification } & \multicolumn{6}{|c|}{ Coding/Data Classification } \\
\hline & $\begin{array}{l}\text { Energy Storing } \\
\text { Water Heater }\end{array}$ & $\begin{array}{l}\text { Magnetic } \\
\text { Refrigerator }\end{array}$ & $\begin{array}{l}\text { Solid State } \\
\text { Refrigeration }\end{array}$ & $\begin{array}{c}\text { NOCO Water } \\
\text { Heater }\end{array}$ & $\begin{array}{c}\text { Tianzun } \\
\text { Air-Conditioning }\end{array}$ & $\begin{array}{c}\text { Xingchu } \\
\text { Refrigerator }\end{array}$ \\
\hline $\begin{array}{l}\text { Structured } \\
\text { interview }\end{array}$ & A1 & B1 & $\mathrm{C} 1$ & D1 & E1 & F1 \\
\hline $\begin{array}{l}\text { Semi-structured } \\
\text { interview }\end{array}$ & A2 & B2 & $\mathrm{C} 2$ & D2 & E2 & F2 \\
\hline Field observation & A3 & B3 & C3 & D3 & E3 & F3 \\
\hline $\begin{array}{l}\text { Enterprise website } \\
\text { and books }\end{array}$ & a1 & b1 & c1 & $\mathrm{d} 1$ & e1 & $\mathrm{f} 1$ \\
\hline $\begin{array}{l}\text { Internal documents } \\
\text { and archives }\end{array}$ & $\mathrm{a} 2$ & b2 & c2 & $\mathrm{d} 2$ & e2 & $\mathrm{f} 2$ \\
\hline $\begin{array}{l}\text { Other case studies } \\
\text { on Haier }\end{array}$ & a3 & b3 & c3 & d3 & e3 & $\mathrm{f} 3$ \\
\hline
\end{tabular}

An important data collection and analysis principle is using and cross-checking multiple data sources, which is often referred to as data triangulation [50]. Data triangulation allows a more reliable, objective, and complete answer to the research problem, and facilitates future generalization. After collecting and coding data for each of the six innovation products, we established an evidence chain for the six sub-cases. Based on comparing similar theoretical constructs among all six evidence chains 
and comparing key concepts related to the value realization of each innovation product/technology, we tried to avoid bias and incompletion of the research findings. The data analysis of the research is elaborated below.

Firstly, based on categorizing and coding qualitative data according to value adding activities such as sources of new technological/product innovation ideas, technological partner selection, collaborative process with technology providers, product manufacturing, and product sales, we explored the key components of Haier's enterprise innovation ecosystem.

Secondly, we categorized and coded data according to non-technological aspects such as strategy, management, culture, institution, organization, and market, to investigate how non-technological innovation ecosystem facilitates the technological innovation ecosystem.

Furthermore, incorporating existing researches, we analyzed the external business environment where the innovation value realization process was embedded, and then identified the ecological niche where Haier is located in the macro environment. Lastly, based on the collaborative process including collaboration motives, principles, modes, and conflicts between Haier and technological providers, we investigated and discussed the relationship management between Haier and ecosystem partners, especially technological providers.

\subsection{Evaluation of the Case Study Design}

Four criteria is usually used to evaluate a case study (i.e., external validity, reliability, construct validity, and internal validity) [50]. As shown in Table 3, we carefully applied the replication principle when choosing the sub-cases and established a case protocol for each sub-case, which shows external validity in the research design. During data collection and analysis, we carefully applied coding and data triangulation, and cross-checked our frameworks with the informants from Haier. This shows that we tried our best to gain reliability and validity in this case study.

Table 3. Reliability and validity of the case study.

\begin{tabular}{cll}
\hline Evaluation Criteria & \multicolumn{1}{c}{ Research Strategy } & Research Stage \\
\hline External validity & $\begin{array}{l}\text { Used the existing theory to guide this case study; } \\
\text { applied the replication principle while investigating } \\
\text { the sub-cases. }\end{array}$ & $\begin{array}{c}\text { research design } \\
\text { research design }\end{array}$ \\
\hline Reliability & $\begin{array}{l}\text { Employed case study protocol. } \\
\text { Built a case study database, cross-checking research } \\
\text { findings from multiple sub-cases. }\end{array}$ & $\begin{array}{l}\text { data collection } \\
\text { data collection }\end{array}$ \\
\hline \multirow{5}{*}{ Construct validity } & $\begin{array}{l}\text { Used multiple sources of evidences: combined } \\
\text { primary data and secondary data. } \\
\text { Established a chain of evidence: the whole processes } \\
\text { of R\&D of different products. } \\
\text { Verify: submitted the report to the person in charge } \\
\text { for checking and approving. }\end{array}$ & $\begin{array}{l}\text { data collection } \\
\text { data collection } \\
\text { data analysis }\end{array}$ \\
\hline Internal validity & $\begin{array}{l}\text { Pattern matching: matched the conceptual model } \\
\text { with the research conclusion; } \\
\text { analyzed possible contradictory research conclusions. }\end{array}$ & $\begin{array}{l}\text { data analysis } \\
\text { data analysis }\end{array}$ \\
\hline
\end{tabular}

\section{Case Findings and Analysis}

In this section, we first analyze the value realization of six product/technological innovation projects cultivated from Haier's innovation ecosystem, and from the six sub-cases we depict Haier's technological innovation ecosystem as shown in Figure 1. After that, we analyze Haier's enterprise innovation ecosystem construction from the ecological niche, non-technological aspects, and macro environments. This answers the first research question regarding the construction of Haier's enterprise innovation ecosystem. Further, we answer the second research question regarding the innovation ecosystem coordination by focusing on how Haier as a core firm coordinates ecosystem actors. 


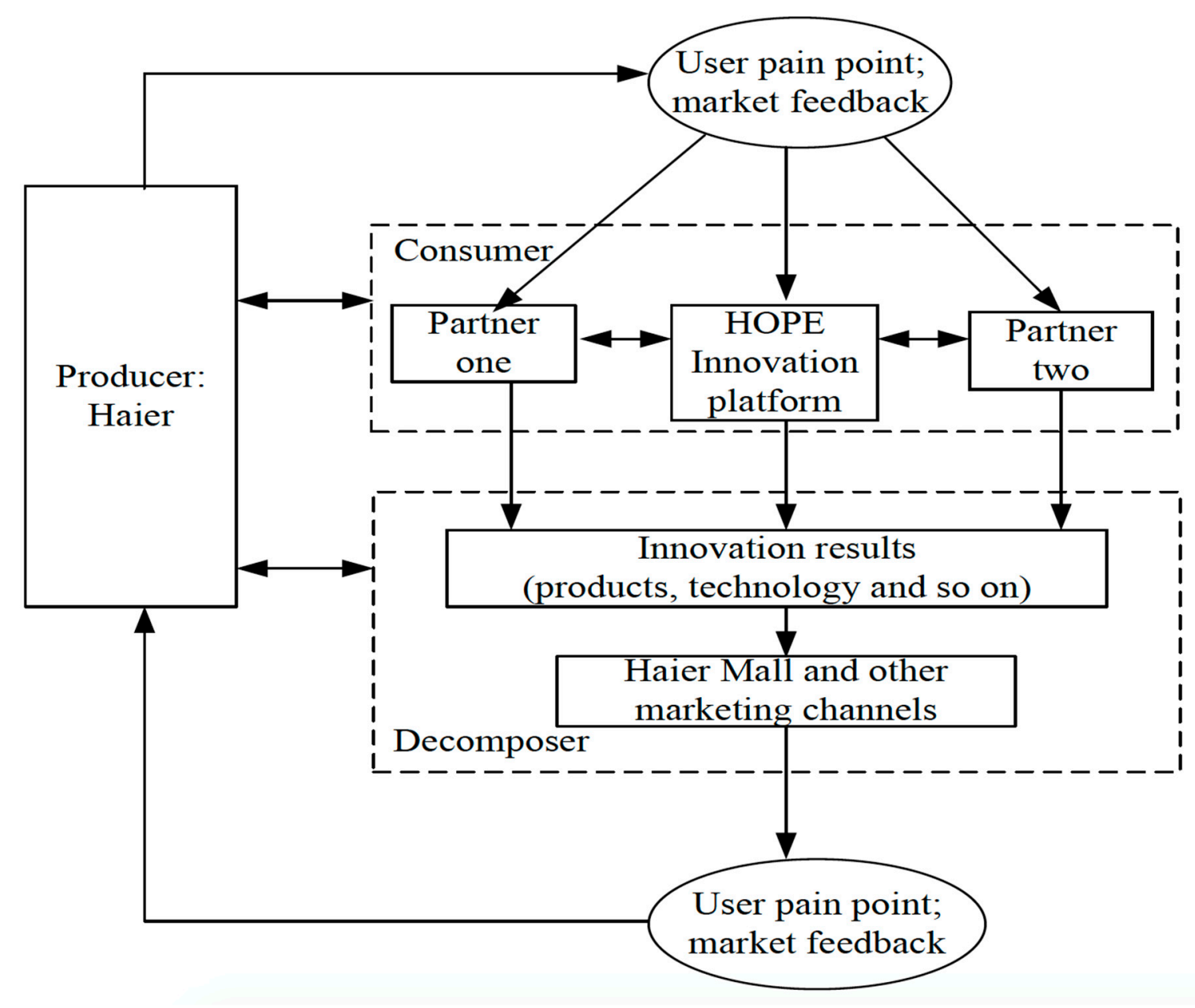

Figure 1. Haier's enterprise technological innovation ecosystem.

\subsection{Six Product/Technological Innovation Projects}

As mentioned earlier, a multi-embedded design was adopted in this study, and the innovation status overview of the six selected product/technological innovations is shown in Table 4. Inspired by key actors of a natural ecological system (producers, consumers, decomposers, non-biological matter, and energy), and the enterprise innovation management theory (impact factors on enterprise innovation performance such as strategy, culture, market, management, institution, technology, etc.), we analyzed the key value realization nodes of the six representative disruptive product/technological innovations released by the Haier Group in recent years, and tried to figure out the key actors and ecological niche of Haier's enterprise innovation ecosystem. 
Table 4. Six innovation projects carried out at Haier's innovation ecosystem.

\begin{tabular}{|c|c|c|c|c|c|c|c|c|}
\hline $\begin{array}{l}\text { Product/ } \\
\text { Technological } \\
\text { Innovation }\end{array}$ & User Pain Points & $\begin{array}{l}\text { Channels of } \\
\text { Selecting Partners }\end{array}$ & $\begin{array}{l}\text { Collaboration } \\
\text { Motives }\end{array}$ & Cooperative Mode & Collaboration Process & $\begin{array}{c}\text { Number of } \\
\text { Main Partners }\end{array}$ & $\begin{array}{l}\text { Type of Main } \\
\text { Partners }\end{array}$ & $\begin{array}{l}\text { Main Partner } \\
\text { Area }\end{array}$ \\
\hline $\begin{array}{l}\text { Energy storage } \\
\text { water heater }\end{array}$ & $\begin{array}{l}\text { Store energy in high } \\
\text { density, minimize } \\
\text { side-effects, be } \\
\text { harmless to health }\end{array}$ & Exhibition & $\begin{array}{l}\text { Technical demand } \\
\text { (to save time and } \\
\text { cost for the } \\
\text { development of } \\
\text { technology) }\end{array}$ & $\begin{array}{l}\text { Provide customized } \\
\text { products for Haier }\end{array}$ & $\begin{array}{l}\text { Link technologies, test } \\
\text { materials, discuss the } \\
\text { details, provide } \\
\text { customized products }\end{array}$ & One & Material firms & Material science \\
\hline $\begin{array}{l}\text { Magnetic } \\
\text { refrigerator }\end{array}$ & $\begin{array}{c}\text { Refrigeration } \\
\text { products are } \\
\text { inefficient and noisy; } \\
\text { national } \\
\text { environmental policy } \\
\text { requirements }\end{array}$ & $\begin{array}{l}\text { Online (innovation } \\
\text { platform) and } \\
\text { offline (research and } \\
\text { development (R\&D) } \\
\text { department) }\end{array}$ & $\begin{array}{l}\text { Technical demand } \\
\text { (developing this } \\
\text { technology is } \\
\text { difficult and needs } \\
\text { lots of time) }\end{array}$ & $\begin{array}{l}\text { Develop the } \\
\text { technology jointly; } \\
\text { share intellectual } \\
\text { property rights and } \\
\text { benefits }\end{array}$ & $\begin{array}{c}\text { Post demand } \\
\text { information, screen } \\
\text { technologies, develop } \\
\text { jointly (Haier provides } \\
\text { research fund), } \\
\text { manufacturing }\end{array}$ & Many & $\begin{array}{l}\text { Firms (technical, } \\
\text { material) and } \\
\text { research } \\
\text { institutes }\end{array}$ & $\begin{array}{l}\text { Chemistry; } \\
\text { space } \\
\text { technology }\end{array}$ \\
\hline $\begin{array}{c}\text { Solid state } \\
\text { refrigeration }\end{array}$ & $\begin{array}{c}\text { Wine cabinet } \\
\text { seriously vibrates, } \\
\text { unable to ensure the } \\
\text { quality of wine }\end{array}$ & $\begin{array}{l}\text { Haier innovation } \\
\text { center in the U.S. }\end{array}$ & $\begin{array}{l}\text { Technical demand } \\
\text { (developing this } \\
\text { technology is } \\
\text { difficult and needs } \\
\text { lots of time) }\end{array}$ & $\begin{array}{l}\text { Develop the } \\
\text { technology jointly }\end{array}$ & $\begin{array}{l}\text { Search for technology, } \\
\text { link technologies, } \\
\text { develop jointly, } \\
\text { manufacturing }\end{array}$ & $\begin{array}{l}\text { One core with } \\
\text { many non-core } \\
\text { partners }\end{array}$ & $\begin{array}{l}\text { Firms and } \\
\text { university }\end{array}$ & $\begin{array}{c}\text { Thermoelectric } \\
\text { material }\end{array}$ \\
\hline $\begin{array}{c}\text { NOCO water } \\
\text { heater }\end{array}$ & Safety issue & $\begin{array}{l}\text { Haier Advanced } \\
\text { R\&D Center }\end{array}$ & $\begin{array}{l}\text { Technical demand } \\
\text { (developing this } \\
\text { technology is } \\
\text { difficult) }\end{array}$ & $\begin{array}{l}\text { Build a joint R\&D } \\
\text { lab between } \\
\text { external research } \\
\text { institute and Haier } \\
\text { R\&D department }\end{array}$ & $\begin{array}{l}\text { Search for technology, } \\
\text { develop jointly, } \\
\text { determine the principle } \\
\text { prototype, determine } \\
\text { the technical prototype, } \\
\text { pilot production, } \\
\text { manufacturing }\end{array}$ & Two & $\begin{array}{l}\text { Research } \\
\text { institutes }\end{array}$ & $\begin{array}{c}\text { Space } \\
\text { technology }\end{array}$ \\
\hline $\begin{array}{l}\text { Tianzun air } \\
\text { conditioner }\end{array}$ & $\begin{array}{l}\text { Traditional air } \\
\text { conditioner is } \\
\text { inefficient and noisy; } \\
\text { air-condition disease }\end{array}$ & $\begin{array}{l}\text { Haier Advanced } \\
\text { R\&D Center }\end{array}$ & $\begin{array}{l}\text { Technical demand } \\
\text { (developing this } \\
\text { technology is } \\
\text { difficult) }\end{array}$ & $\begin{array}{l}\text { Purchase core } \\
\text { technology; then } \\
\text { improve the } \\
\text { technology with } \\
\text { other external } \\
\text { partners } \\
\end{array}$ & $\begin{array}{c}\text { Post demand } \\
\text { information, screen } \\
\text { technology, purchase } \\
\text { core technology, } \\
\text { improve the technology } \\
\text { jointly, production }\end{array}$ & $\begin{array}{l}\text { One core with } \\
\text { many non-core } \\
\text { partners }\end{array}$ & $\begin{array}{l}\text { University, } \\
\text { research } \\
\text { institutes, firms } \\
\text { (home } \\
\text { appliance) }\end{array}$ & $\begin{array}{c}\text { Space } \\
\text { technology; } \\
\text { aerodynamics }\end{array}$ \\
\hline $\begin{array}{l}\text { Xingchu } \\
\text { refrigerator }\end{array}$ & $\begin{array}{l}\text { Vegetables in the } \\
\text { refrigerator are easy } \\
\text { to dry out; while } \\
\text { herbal medicines are } \\
\text { easy to become damp }\end{array}$ & $\begin{array}{l}\text { Haier Advanced } \\
\text { R\&D Center }\end{array}$ & $\begin{array}{l}\text { Technical demand } \\
\text { (to save time and } \\
\text { cost for the } \\
\text { development of } \\
\text { technology) }\end{array}$ & $\begin{array}{l}\text { Develop the } \\
\text { technology jointly; } \\
\text { independent R\&D }\end{array}$ & $\begin{array}{l}\text { Post demand } \\
\text { information, filter } \\
\text { techniques, develop } \\
\text { jointly, production }\end{array}$ & One & $\begin{array}{c}\text { Firms } \\
\text { (technical) }\end{array}$ & $\begin{array}{l}\text { High humidity } \\
\text { technology }\end{array}$ \\
\hline
\end{tabular}




\subsection{Haier's Enterprise Innovation Ecosystem Construction}

\subsubsection{The Ecological Niche of Haier's Technological Innovation Ecosystem}

Based on analyzing the above six technological innovation projects, the construction of Haier's technological innovation ecosystem can be extracted and described as follows in Figure 1. The "squares" represent the main actors and species within Haier's innovation ecosystem, and the arrows between these species show the flow of resources and hereby depict the interdependent relationships between the actors. The positions of actors show their ecological niche within the innovation ecosystem, which are symbiotic. Table 5 provides an overview of how value realization is achieved at Haier's innovation ecosystem.

First, Haier adopts the user-oriented principle. Users act as "seeds", and their pain points are a major source of creative new ideas, as well as key drivers of Haier's innovation activities. The popularity of Information Communication Technology significantly improves problems such as information asymmetries and delay of information transferring between corporations and users, which allows continuous and smooth interactions between enterprises and users and allows user innovation and user driven innovations during the whole innovation process.

Second, an innovation platform acting as a "bee" is key for an enterprise innovation ecosystem. In the Haier case, HOPE is an online platform that acts as an effective channel facilitating each of Haier's divisions to seek suitable partners. Alongside a physical online platform, the platform we propose here also includes an "invisible platform" that with an open boundary unites the core firm and global innovation partners and resources. The invisible and borderless innovation platform gathers and integrates internal and external innovation resources for certain technologies, and through various forms of partnerships, optimizes innovation resource allocation within the innovation ecosystem, and thus further improves the dynamism and creativity of the whole enterprise innovation ecosystem.

Third, various forms of actors act as "species" within an innovation ecosystem, and the co-existence of cooperation and competition, and interactions between the core firm and actors allow them to co-evolve. In the case of Haier, on the one hand, based on complementary resources and advantages, Haier collaborates with research institutions (e.g., NOCO (none CO emission) water heater project), universities (e.g., Tianzu air conditioner), firms (e.g., energy storage water heater), technological transfer organizations (e.g., Xinchu refrigerator), etc. This not only creates a reciprocal situation among ecosystem actors, but also at the same time continuous offers improve products and services to users and society. On the other hand, the Haier Group establishes a partnership with sales distributors, and relying on their sales networks, innovation results are transferred and launched to the market and finally realized value. At the same time, distributors can collect users' comments on new products, and the next round of product/technological innovation can be initiated based on feedbacks from users.

In summary, various actors are bridged through Haier's innovation platform HOPE, and aligned based on a common value proposition, and their complementary resources and capabilities. It is worth noting that though Haier is a core firm, it is not located at a top position within the ecosystem, meaning that though the ecosystem has layers, it does not mean Haier has top-down control over the other actors. Another important issue is that at each ecological niche, there does not need to be a specific firm or organization; rather it can be a group of firms that compete and cooperate with each other and freely enter and exit with the facilitation of the innovation platform. This ensures the sustainable innovation potential of the whole ecosystem. 
Table 5. The value realization process of Haier's technological innovation ecosystem (coding and illustrative quotes).

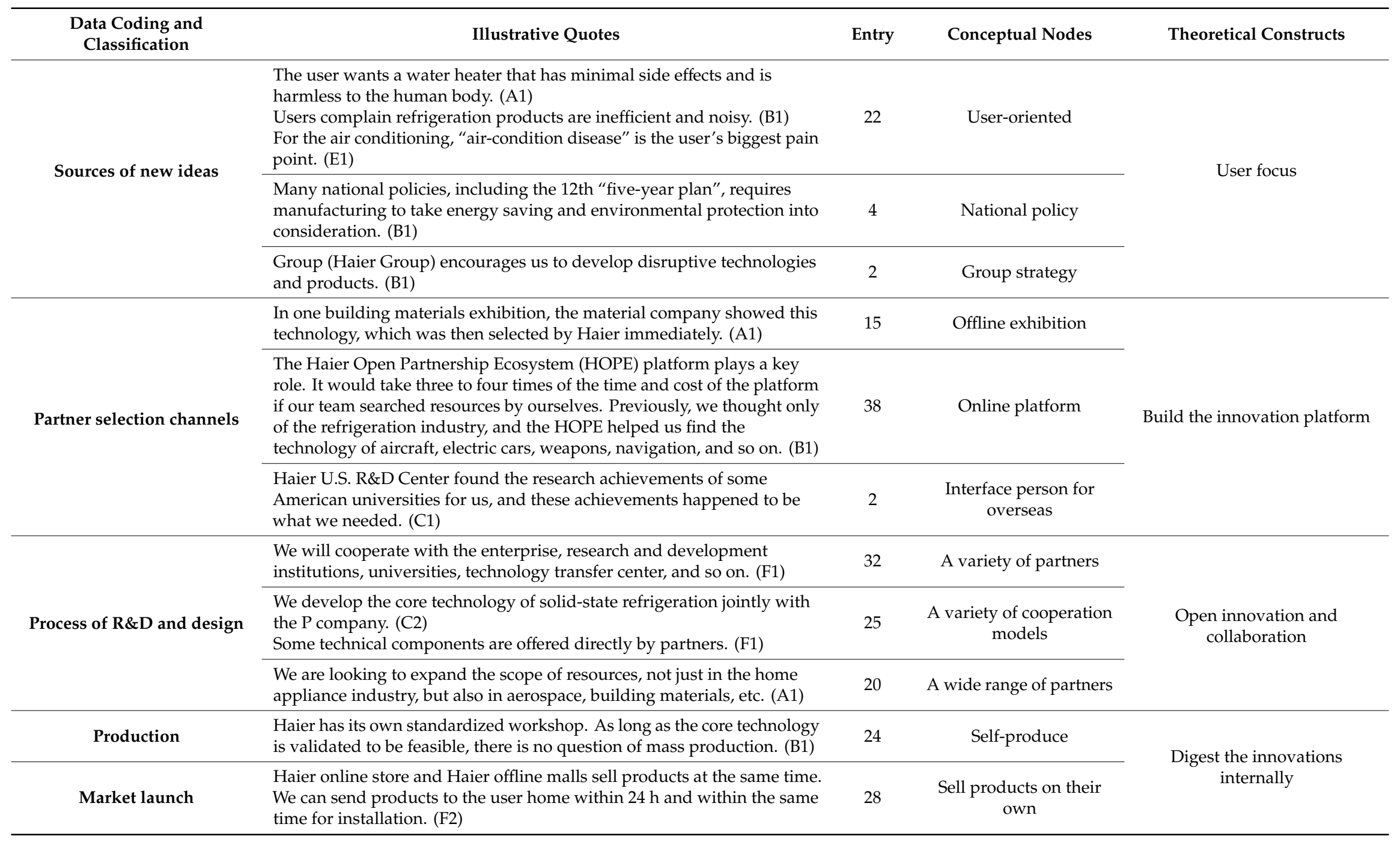




\subsubsection{The Non-Technological Innovation Aspects of Haier's Enterprise Innovation Ecosystem}

Besides technological aspects, non-technological aspects such as strategy, management, culture, institution, organization, and market, is another focus of this research. Table 6 provides an overview of how non-technological aspects support the Haier Group's enterprise innovation ecosystem. Based on qualitative data analysis, the ecological niche of Haier's non-technological innovation ecosystem can be described as follows.

- Strategic innovation as the lead:

Strategic innovation of the core firm can pinpoint the developmental direction of the whole group. Strategic innovation defines which user value should be created and identifies ways of achieving those values.

Haier describes the corporate objective as a "borderless enterprise, leadership-free management, and scale-free value chain". Guided by the strategic innovation blueprint, and regarding users' complaints as the innovation driving force, Haier proactively interacts with users during the process of research, design, development, and manufacture. In order to facilitate the user-oriented process and interactions with users, Haier has changed its organizational structure from highly bureaucratic to an inverted pyramid. Through the user forcing mechanism, each of Haier's employees has to face their customers directly. In line with strategic innovation, the Haier Group devotes itself to developing world-leading disruptive products/technologies, constructing innovation platforms, and integrating frontier technological resources to fulfill the increasingly complex and personalized user needs.

- Management innovation as the lubricant:

Enterprise innovation performance is directly impacted by its management. It has become common sense that managers are required to dynamically assess the current situation (i.e., internal and external environment), seize opportunities, acquire resources, and continuously innovate to ensure the congruence and co-evolution of corporate strategy, culture, organization, institution, and technological innovation.

The Haier Group invented and proposed the management model of "win-win between people and order". "People" refers to Haier's employees, while "order" refers to user value. This indicates that Haier's employees' contributions and own value are reflected from how much user value they create. Later on, Haier broke down the bureaucratic structure, and disruptively changed the organizational structure to an inverted pyramid. Corresponding to the organizational change, Haier promoted the development of small and micro enterprises within the group and organized them on a common innovation platform. The essence of Haier's management innovation is to let employees and resources converge and diverge based on orders, which allows all employees and actors to fully discover and utilize their potential and capacities. This will further create value for individuals, the Haier Group, and users and customers.

- Cultural innovation as a support:

The generation of innovative ideas, idea conversion, and commercialization of innovation results are all inevitably impacted by the corporate culture. An innovative culture may provide a benign and positive atmosphere that encourages and facilitates the innovative and entrepreneurial activities of employees, and the positive relationship between corporate culture and innovation performances has been proven by existing researches [51].

Inspired by the open innovation paradigm [46], Haier never excludes external technologies. In order to achieve a win-win situation, Haier usually establishes a R\&D partnership rather than merger and acquisition and is willing to provide partners with needed resources and platforms. Within Haier, the innovative corporate culture advocates beliefs such as "the entire globe is my R\&D department" and "everyone engages in innovation", and encourages every Haier employee to innovate and transform ideas into practice. Walking around the Haier industrial park, slogans such as "no rewards without 
user payment" and "no people working outside of an entrepreneurial SME (small and medium-sized enterprises) show that employee-driven innovation has become a generic feature of Haier.

- Institutional innovation as a driving force:

The cultivation and maintenance of an innovative culture requires institutional support. Institutional innovation and technological innovation are closely bonded and mutually enhance each other, which is essential for the sustainable development of the whole group.

Haier's pioneering institutional innovation sets a foundation to its innovative culture, leads to organizational change, and then continuously infuses vitality to the development of the whole group. Haier promotes user-orientation principles, and based on the reversed forcing mechanism, all internal self-organizing SMEs and external suppliers are urged to commit to the whole process in order to optimize budgeting and achieve the desired objectives. The "reversed forcing mechanism" allows all employees to face their users and customers directly, which on the one hand can perceive market changes timely and seize users' needs precisely, and on the other hand can facilitate the delayering, dynamism, and networking of the organizational structure.

- Organizational innovation as infrastructure:

Organizational innovation is a complicated process that involves changes in various aspects and factors. Fundamentally, organizational innovation is the adoption and application of a new structure or method that leads to process, product, or technological innovations that brings new value to the organization [52].

The Haier Group is transforming and decomposing a giant corporation into many SMEs. Facilitated by an innovation platform, the SMEs are dynamically networked and synergistically respond to the fast-changing business environment with disruptive products and technologies. Organizational innovation supports the objective of involving every employee in the innovation process and disrupts the traditional managerial mode of top-down resource allocation and decision-making. Every employee is empowered to make their own decisions, allocate resources, create value to users/customers, and distribute gained value. In summary, Haier's experiences provide the coupling development of organizational innovation and technological innovation.

- Market innovation as an approach:

The ultimate purpose of innovations is commercialization and value realization. That is to say, market innovation is the final value realization approach that supports the operation of enterprise technological innovation ecosystems. The Haier Group uses its "virtual-real" marketing and sales networks to continuously extend its market. Two sales platforms (i.e., the Haier Mall and "Day and Day Logistics"), provide personalized and customized services for Haier's users based on their needs and ensures satisfactory services such as delivery within $24 \mathrm{~h}$ and integrated delivery and settlement in one order. 
Table 6. The non-technological issues of Haier's innovation ecosystem.

\begin{tabular}{|c|c|c|c|c|}
\hline Coding \& Classification & Illustrative Quotes & Entry & Conceptual Nodes & Theoretical Construct \\
\hline \multirow{3}{*}{ Strategy } & $\begin{array}{l}\text { The user wants a water heater that has minimal side effects and is harmless to the } \\
\text { human body. (A1) } \\
\text { Users complain refrigeration products are inefficient and noisy. (B1) } \\
\text { For the air conditioning, "air-condition disease" is the user's biggest pain point. (E1) }\end{array}$ & 22 & User-oriented & \multirow{3}{*}{ Strategy as the lead } \\
\hline & $\begin{array}{l}\text { In the process of product development and design, we constantly interact with the } \\
\text { users. (F1) }\end{array}$ & 24 & User interaction & \\
\hline & $\begin{array}{l}\text { Group (product development group) encourages us to develop disruptive } \\
\text { technologies and products. (B1) }\end{array}$ & 2 & Group strategy & \\
\hline Management & $\begin{array}{l}\text { Our team depends on the project. In one team, we all have different expertise, } \\
\text { complementary to each other, forming a strong core competitiveness within the } \\
\text { team. There is a sense of competition between employees, making everyone strive } \\
\text { for more projects and to create more value. (C1) }\end{array}$ & 26 & $\begin{array}{l}\text { Management model of } \\
\text { "combining employee with } \\
\text { project" }\end{array}$ & Management as the foundation \\
\hline \multirow{3}{*}{ Culture } & $\begin{array}{l}\text { Many companies choose to merge with their technical partner, but we think it is } \\
\text { good for a partner to develop and grow. We prefer open innovation and their own } \\
\text { growth, to keep the source of innovation, but we provide them with the resources } \\
\text { needed and the platform. (C1) }\end{array}$ & 10 & \multirow{2}{*}{ The idea of open innovation } & \multirow{3}{*}{ Culture as the guide } \\
\hline & $\begin{array}{l}\text { The HOPE platform plays a key role, it can find global resources and release } \\
\text { innovation requirements and the latest technology, matching technology and } \\
\text { resource quickly and accelerating the product innovation process. (B1) }\end{array}$ & 28 & & \\
\hline & $\begin{array}{l}\text { Haier wants to raise every employee to be well-rounded. I was an engineering } \\
\text { graduate, but in Haier, I needed to not only take advantage of my engineering, but } \\
\text { also exercise my ability in other aspects. I needed to directly face my own customers } \\
\text { and the market and communicate with different types of people. I feel I have } \\
\text { become a well-rounded talent. (C1) }\end{array}$ & 24 & Everyone can be CEO & \\
\hline Institution & $\begin{array}{l}\text { The Haier Group internally uses reversed forcing mechanism step-by-step, that is, } \\
\text { each staff member must meet face to face with their own users. The whole process, } \\
\text { from the enterprise internal management body to the external suppliers, uses the } \\
\text { reversed forcing system. (d1) }\end{array}$ & 26 & Reversed forcing system & Institution as the motive force \\
\hline Organization & $\begin{array}{l}\text { Through "micro" corporations, Haier makes frontline employees operate } \\
\text { independently according to the market and user needs, speeding up the whole } \\
\text { innovation process. (C1) }\end{array}$ & 25 & Flattening organization & Organization as the guarantee \\
\hline Market & $\begin{array}{l}\text { Our group has our own custom factories, such as Shenyang and Zhengzhou. They } \\
\text { provide customized services for users; users can see their production progress and } \\
\text { logistics information of orders at home and at any time. We try to ensure that users } \\
\text { can receive satisfactory products at home with the quickest speed. (F2) }\end{array}$ & 13 & Customized services & Market as the approach \\
\hline
\end{tabular}




\subsubsection{The Macro Environment of Haier's Innovation Ecosystem}

Haier's external innovation environment can be illustrated from the following four aspects (i.e., market, political, cultural, and resource environments).

First, the market environment directly determines the innovation process of the enterprise innovation ecosystem as the final stage of the innovation process, commercialization, and value realization of new ideas. A benign and trustful market environment encourages the coopetition between innovators, and thus facilitates the establishment and development of the innovation ecosystem. Market needs are the main driving force of corporate innovation; while at the same time, the increasingly fierce market competition urges individual firms to join one or several enterprise innovation ecosystems as no individual firm can survive alone nowadays.

Second, the policy environment ensures the operation of an enterprise innovation ecosystem. Financial policies supervise and facilitate firms' financing and investment decisions. Intellectual property protection laws regulate the flow of intellectual properties such as knowledge and human resources between firms and promote technological innovations. Moreover, the government utilizes multiple policy instruments to regulate the environment and identifies development directions for firms. For instance, Haier put a lot of effort into developing the magnetic refrigeration technology to respond to the call for energy conservation and environment protection policies.

Third, the cultural environment may indirectly influence the construction and operation of an enterprise innovation ecosystem, which also significantly determines the survival and sustainability of an enterprise innovation ecosystem. A corporate culture that promotes innovation may encourage the employees' innovation enthusiasm and potential, and further promotes an innovative atmosphere in the society. Currently, the Chinese government advocates "mass entrepreneurship and innovation", which is in line with the construction and completion of Haier's internal entrepreneurial platforms including the HOPE, HaierIdea platform, and U-home ecosphere. The maturity of these entrepreneurial platforms attracts entrepreneurs and incubates more and more SMEs, and thus promotes the entrepreneurial tide within the cross industries

Lastly, the resource environment provides supports for the development of an enterprise innovation ecosystem and is an indispensable component of enterprise innovation activities. A resource environment consists of both tangible resources such as human resources and physical resources, and intangible resources such as knowledge and technologies. An enterprise innovation process involves constant resource exchanges between the core firm and external resource environment. For example, the Haier Group collaborates with financial intermediaries and technology transfer offices to get sufficient resources to support the operation of the enterprise innovation ecosystem.

\subsection{Enterprise Innovation Ecosystem Coordination}

Successful enterprise innovation ecosystem coordination can continuously incubate innovations for value creation and thus contribute to ecosystem sustainability. Haier as a core firm with its ecosystem actors is illustrated in Table 7 from four aspects: cooperation motives, ecosystem principles, value co-creation and appropriation mechanisms, and ecosystem conflict management. This also echoes Section 2.3 . 
Table 7. Collaboration between Haier and its partners.

\begin{tabular}{|c|c|c|c|c|}
\hline $\begin{array}{l}\text { Data Coding } \\
\text { \& Classification }\end{array}$ & Illustrative Quotes & Entry & Conceptual Nodes & Theoretical Construct \\
\hline \multirow{3}{*}{ Cooperation motives } & $\begin{array}{l}\text { The core technology involved in new types of material and structure, so } \\
\text { technology enterprises must have decades of experience of R\&D to do it. } \\
\text { Haier alone cannot develop the technology in the short term. (C1) }\end{array}$ & 19 & Shorten the innovation process & \multirow{3}{*}{ Techno-complementarity } \\
\hline & $\begin{array}{l}\text { Generally, technical innovation requires higher development costs, so we } \\
\text { can find a technology provider to reduce our R\&D costs and accelerate the } \\
\text { time to market. (D1) }\end{array}$ & 24 & Saving the cost of innovation & \\
\hline & $\begin{array}{l}\text { Disruptive technology innovation is highly risky, so we choose to } \\
\text { cooperate with other partners and take advantage of each other's core } \\
\text { competence. (B1) }\end{array}$ & 28 & Reduce the risk of innovation & \\
\hline \multirow{3}{*}{ Ecosystem principles } & $\begin{array}{l}\text { We consider mainly laboratory equipment of colleges and R\&D centers } \\
\text { and the research experience of professors. (F1) }\end{array}$ & 12 & R\&D ability & \multirow{3}{*}{$\begin{array}{l}\text { Technology complementarity; } \\
\text { non-technological compatibility }\end{array}$} \\
\hline & $\begin{array}{l}\text { We consider the product prototype the enterprise provided and whether it } \\
\text { can realize volume production and whether it has the potential of } \\
\text { commercialization. (F1) }\end{array}$ & 15 & Technical feasibility & \\
\hline & $\begin{array}{l}\text { Tardiness is a common problem for products within the R\&D period. } \\
\text { Therefore, the execution of the partner's team is an important factor we } \\
\text { consider (D1) }\end{array}$ & 27 & Team executive ability & \\
\hline \multirow{3}{*}{$\begin{array}{l}\text { Value co-creation } \\
\text { mechanisms }\end{array}$} & $\begin{array}{l}\text { Magnetic refrigeration technology adopted joint R\&D. Haier contributed } \\
\text { its advantage in terms of system matching and design for home appliance, } \\
\text { and the partner provided magnetic refrigeration technology since it has } \\
\text { many years of research experience. (B1) }\end{array}$ & 10 & Joint R\&D & \multirow{3}{*}{$\begin{array}{l}\text { Diversification; } \\
\text { depends on the specific project }\end{array}$} \\
\hline & Both sides define each stage of output and pay according to the stage. (a6) & 8 & $\begin{array}{c}\text { Commissioned technological } \\
\text { development }\end{array}$ & \\
\hline & $\begin{array}{l}\text { For a component module, we choose direct delivery; generally, the } \\
\text { suppliers would become secondary suppliers. For overseas companies, we } \\
\text { will choose the way such as a one-time purchase. (F1) }\end{array}$ & 26 & Direct delivery & \\
\hline \multirow[t]{2}{*}{$\begin{array}{l}\text { Ecosystem conflicts } \\
\text { management }\end{array}$} & $\begin{array}{l}\text { For the two most common types of problems of project tardiness and } \\
\text { ownership of the patent right, we would communicate timely, ensuring the } \\
\text { progress of the project. (B1) }\end{array}$ & 23 & Communication management & \multirow{2}{*}{$\begin{array}{l}\text { The supporting role of } \\
\text { non-technology innovation } \\
\text { system }\end{array}$} \\
\hline & $\begin{array}{l}\text { When cooperating with foreign technology partners, we often have conflict } \\
\text { because of different cultural backgrounds and payment accounting. (C1) }\end{array}$ & 28 & Culture management & \\
\hline
\end{tabular}


- Cooperation motives:

Haier's cooperation motives vary due to the different natures of partners. Cooperation with universities and research institutions are usually at the conceptualization and research phase of innovative products/technologies. The main motive of Haier is accessing the cutting-edge technologies, while Haier's partners focus on IP issuing and academic title promotion. The technological partnerships between Haier and technological providers are usually based on resource and advantage complementarities. The major considerations are technology feasibility, possibility of commercialization, and reasonable costs. In collaborations between Haier and well-known enterprises such as the global 500 companies, the main motive is to improve the application of the innovative technologies, provide solutions for customers and fulfill users' needs, and further create value for all parties. Moreover, Haier collaborates with small or start-up companies with the purpose of accelerating the commercialization of technologies; while the partners wish to generate profits in the short-run, maintain a health case flow, and lower the risks of enterprise operation.

- Ecosystem principles:

The major criteria and principle of technological partner selection is the complementarities of technologies. Apart from technological complementarities, some other criteria are also considered due to different projects and partners. For example, potential partners' brands (i.e., whether it is a well-known company), qualifications (i.e., it has successful collaboration experiences with the top three home appliance suppliers), and the team (i.e., whether the team leader has experience in managing technological partnerships, and whether the team has the required executive forces and cultural compatibility) are all considered.

- Value co-creation mechanisms:

The Haier Group adopts several collaboration mechanisms with its partners according to different projects and resource requirements: (1) commissioned development based on negotiations and agreements between Haier and the partners, determining deliverables at different phases, and the amount of commissions; (2) joint development and R\&D knowledge and results sharing; (3) subcontracting modular components to qualified suppliers and signing exclusive and long-term agreements; (4) establishing long-term strategic partnerships through multiple mechanisms such as setting up joint labs, brand collaborations, sharing channels, etc., in order to achieve synergic effects; (5) patent cooperation through jointly establishing patent pool, patent buyout, and patent licensing, in order to develop disruptive products/technologies in the shortest possible time.

- Ecosystem conflict management:

Besides facilitating value co-creation, the sustainability of partnerships depends highly on ensuring value appropriability. To achieve this, cultural compatibility, resource complementarity, and more importantly, an effective communication mechanism are needed. While cooperating with other enterprises, especially foreign firms, cultural differences and geographical distances may cause communication difficulties and even conflicts such as the patent ownership, value distribution and appropriation, and project progress. Haier promotes the entrepreneurial culture of "everyone is $\mathrm{CEO}^{\prime \prime}$, and every employee is directly facing his/her customers. Therefore, Haier's employees are trained and transformed from technical experts to well-rounded talents that have problem-solving skills, communication skills, and project management capabilities that ensure the smooth progress of individual innovation projects and timely delivery. 


\section{Discussion and Conclusions}

\subsection{A Core Firm Based Innovation Ecosystem}

This study adopted a single case study design, and through investigating six embedded sub-cases (i.e., six disruptive product/technological innovations developed and released by Haier in recent years), we explored the construction mechanism and coordination of an enterprise innovation ecosystem from a core-firm based view. Integrating the technological innovation ecosystem, non-technological aspects, and the macro environment, Figure 2 depicts an comprehensive enterprise innovation ecosystem.

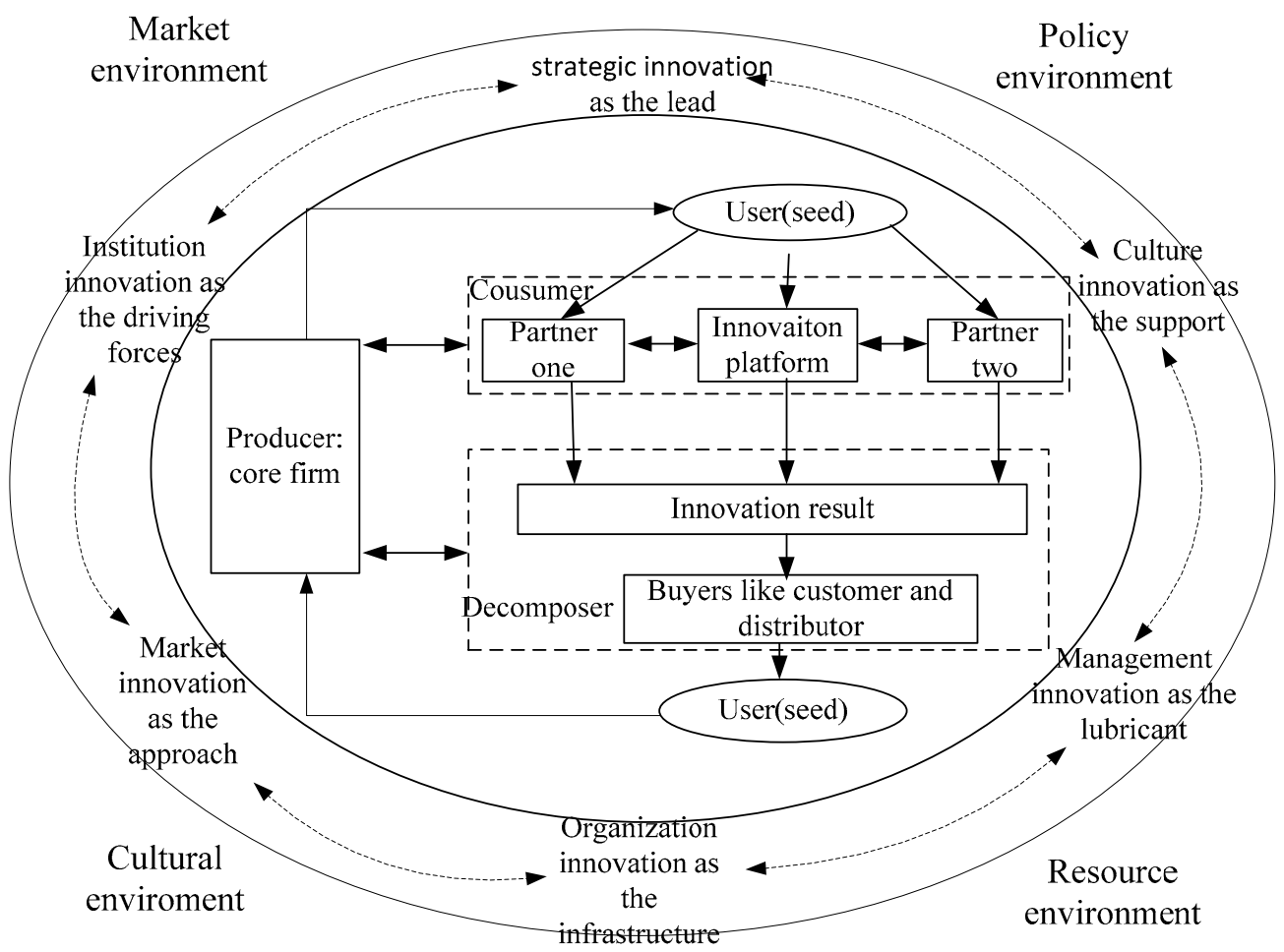

Figure 2. A core-firm based innovation ecosystem.

First, Haier as a core firm successfully constructs an enterprise innovation ecosystem for continuous value co-creation. Facing the external competitive business environment and following the user-oriented principle, the core firm constructs an innovation platform, connects, interacts, and collaborates with different organizations and individuals at different levels. Through mutual interests sharing, technological complementarities, and co-evolution, a core-firm based enterprise innovation ecosystem is thereby constructed. Alongside technological factors, the innovation ecosystem is also supported by non-technological factors such as strategy, management, organization, culture, institution, and market.

Second, the coordination of the innovation ecosystem ensures value appropriability and reduces conflicts between partners. The initiation of a partnership is based on technological and resource complementarities, and a set of principles such as technology feasibility, technology commercialization, and reasonable costs are also considered. With the purpose of pursing mutual interests, the collaboration modes between the core firm and its partners vary based on different projects and the nature of partnerships. An open and innovative culture can act as a lubricant when conflicts occur. The platform and network based flat organization and management mode allows individual employees to face his/her customers directly and is therefore urged to flexibly and dynamically deal with potential problems arising during the innovation process. 


\subsection{Implications and Reflections on Sustainability}

As the world's leading home appliance supplier and industrial leader, Haier's experiences provide implications and inspirations to both theories and practice. We will elaborate on the theoretical and practical implications of this study below, with specific reflection on sustainability.

Regarding theoretical implications and contributions, this study contributes to the gap of innovation ecosystem theorizing [8] and its coordination, and it contributes to literature on Chinese firms' innovation ecosystem construction and coordination. Unlike previous studies on innovation ecosystems which emphasize the technological interdependence between various ecosystem actors, and how specific technological innovations are developed and upgraded [14,24], we highlight the importance of non-technological aspects of an enterprise innovation ecosystem, and argue that the compatibility among technological and non-technological aspects are vital for the formation and sustainability of an innovation ecosystem. In response to the criticism on lack a of "eco" in previous innovation ecosystem literature [11], we identify ecological niches within Haier's innovation ecosystem, and unfold their symbiotic relationships. The interdependence and symbiosis help the whole ecosystem to achieve a dynamic balance and hence facilitate its sustainable evolution.

Regarding practical and managerial implications, this case study on Haier's enterprise innovation ecosystem shares timely experiences on how a core firm can construct and coordinate an innovation ecosystem to achieve a sustained innovation outcome that creates sustainable value to society, which in return brings sustained competitive advantages to the core firm. From an in-depth analysis, we highlight the user-centered principle and Haier's role as a facilitator rather than a commander. A core firm is not the predator that threatens others in an ecosystem, or has a top-down control over others. This is very important to cultivate a flexible and incentive innovation culture to stimulate value creation potential of all ecosystem partners. Apart from value creation, it is also very important for a core firm to ensure value appropriability and individual benefit of ecosystem partners, which is vital for the sustainability of the whole ecosystem.

Responding to our argument in Section 2.1 regarding sustainability as an inherent nature of an innovation ecosystem, the Haier case shows how a core-firm based innovation ecosystem is in line with sustainability in the following aspects.

First, innovation projects with sustainability concerns enhance social welfare and sustain economic growth, and their continuous upgrading deepen the interdependence and symbiosis between partners. This in return shapes the innovation ecosystem and facilitates the sustainable evolution of the whole ecosystem. Further, the sustainability of an innovation ecosystem can then cultivate more innovations to fulfill the sustainability pursuits from economic, societal, and environmental aspects. Thus, the endless and benign evolution of an innovation ecosystem is ensured.

Second, case findings suggest integrating technological and non-technological issues when constructing an innovation ecosystem and emphasize the importance of ecosystem coordination that ensures individual value appropriability. For instance, only a sustainability-oriented strategy, and an open and flexible entrepreneurial culture, can better link global complementary knowledge resources and innovators to align in an innovation ecosystem. Only when an individual actor's value appropriability is ensured, can an ecosystem balance the tension between competitive and cooperative tensions. This is also essential to maintain sustainable symbiotic and interdependent relationships between actors.

Third, we specifically highlighted a "mind-set" shift shown in Haier's experiences. Hwang and Horowitt [20] argue a secret of Silicon Valley's success as a regional innovation ecosystem is that it does not emphasize the success of a specific firm such as Google or Facebook, rather it enhances the overall entrepreneurial success rate of the innovation ecosystem. Reflecting on the Haier case, although we chose six "successful" projects as sub-cases, it does not mean that Haier emphasizes on the success of these specific projects. The truth is that within Haier's innovation ecosystem, there are hundreds of innovation projects incubated every year and there are also many ideas which perish. Embedded in Haier's innovation ecosystem, or innovation rainforest, with an open culture that encourages adventure 
and entrepreneurship, global innovators interact and seek their own growth path facilitated by the core firm Haier, rather than be controlled or determined. This helps the release of innovation potential, existence, and sustainability of the whole innovation ecosystem. This is extremely important for policymakers and business managers that want to cultivate and coordinate an ecosystem. A mindset shift is needed (i.e., more efforts should be focused on the system level rather than specific technology or project level) to pursue a sustainable ecosystem rather than the success of specific projects or technological innovations. This also raises an issue for researchers to reflect on innovation ecosystem studies on cultivating specific projects or firms.

In summary, innovation ecosystem has become a buzzword in recent years, and many firms want to establish or strengthen their enterprise innovation ecosystem to earn sustainable development and competitive advantages. Our findings add to the supporting role of non-technological innovation to the construction of an innovation ecosystem, stress the interaction between technological innovation and non-technological innovation, and provide implications to innovative companies on constructing a core-firm based innovation ecosystem. Haier's experiences and the timely research findings of this study also provide insight for other firms and thus have generalization possibilities.

\subsection{Limitations and Future Research Directions}

Besides the theoretical and practical implications discussed above, this study also has limitations which provide future research possibilities.

In terms of the multi-embedded research design, we chose six product/technological innovations released by Haier in recent years as sub-analytical units, and all six innovations were disruptive. That is to say, no incremental or process innovations were considered in this study, which may also have complementary and supplementary findings to our conclusions. Due to accessibility of data, we have less knowledge on the manufacturing and sales phases of some of the sub-cases, and thus have limitations on analyzing the value realization process.

This study is a single exploratory case study on Haier's experiences. Yet, while exploring the establishment and coordination of collaborative relationships, the core firm's own nature needs to be taken into consideration. Though Haier's experience can be generalized to other firms, due to the different nature and industries, other firms' ecosystem construction and coordination may show different patterns. For instance, a Chinese mobile phone manufacturer, Xiaomi, is constructing a user-centered innovation ecosystem and providing innovative products and services that can be connected by the mobile phone with the vision of a sustainable and better lifestyle. That is to say, the core firms are different in nature, one is from a traditional manufacturing industry (Haier), and the other is from the ICT industry (Xiaomi). In response to the trend of "Internet of Things" (IoT), which ecosystem can achieve better innovation performance and sustainability? A comparative study on different innovation ecosystems and the competition between ecosystems can be a future research direction. Yet, this study is mainly in response to the gap in understanding and theorizing the innovation ecosystem. Further, this case study provides a general overview of Haier's innovation ecosystem and therefore is limited in depicting detailed mechanisms or interactions. Thus, considering current research findings and limitations, there are some other future research possibilities. This study mainly considers the construction of a core-firm based innovation ecosystem; a more detailed and specific investigation on how the core firm coordinates and facilitates the innovation ecosystem along its lifecycle can be carried out. Specifically, researches on how ecosystem actors balance the tension between cooperation and competition at different stages of the innovation process and ecosystem development would be interesting, echoing popular research trends on coopetition and innovation ecosystem [32,41]. Finally, in order to apply the theoretical generalization principle, and to test and improve our research findings, multiple case studies on several core firms and their enterprise innovation ecosystems can be carried out. 
Author Contributions: The authors contributed in the following ways: conceptualization, S.J. and Y.H.; Data curation, S.J. and Z.W.; formal analysis, S.J., Y.H. and Z.W.; funding acquisition, S.J. and Y.H.; methodology, Y.H. and Z.W.; project administration, S.J.; resources, S.J.; rupervision, S.J. and Y.H.; validation, Y.H.; writing-original draft, S.J., Y.H. and Z.W.; writing-review and editing, Y.H.

Funding: This research is supported by the National Science Foundation of China, No. 71874048 and the Aalborg University Social Science Faculty Talent Program, No. 760738.

Conflicts of Interest: The authors declare no conflicts of interest.

\section{References}

1. Silvestre, B.S.; Ţî̀rcă, D.M. Innovations for sustainable development: Moving toward a sustainable future. J. Clean. Prod. 2019, 208, 325-332. [CrossRef]

2. Zeng, D.; Hu, J.; Ouyang, T. Managing innovation paradox in the sustainable innovation ecosystem: A case study of ambidextrous capability in a focal firm. Sustainability 2017, 9, 2091. [CrossRef]

3. Boons, F.; Montalvo, C.; Quist, J.; Wagner, M. Sustainable innovation, business models and economic performance: An overview. J. Clean. Prod. 2013, 45, 1-8. [CrossRef]

4. Oksanen, K.; Hautamäki, A. Sustainable Innovation: A Competitive Advantage for Innovation Ecosystems. Technol. Innov. Manag. Rev. 2018, 5, 24-30. [CrossRef]

5. Klewitz, J.; Hansen, E.G. Sustainability-oriented innovation of SMEs: A systematic review. J. Clean. Prod. 2014, 65, 57-75. [CrossRef]

6. Adner, R. Ecosystem as Structure: An Actionable Construct for Strategy. J. Manag. 2016, 43, 39-58. [CrossRef]

7. Paavo, R.; Almpanopoulou, A. In defense of "eco" in innovation ecosytem. Technovation 2017, 61, 39-42.

8. Jacobides, M.G.; Cennamo, C.; Gawer, A. Towards a theory of ecosystems. Strateg. Manag. J. 2018, $2255-2276$. [CrossRef]

9. Mcintyre, D.P.; Srinivasan, A. Networks, platforms, and strategy: Emerging views and next steps. Strateg. Manag. J. 2006, 127, 12-13. [CrossRef]

10. Lee, I.; Shin, Y.J. Fintech: Ecosystem, business models, investment decisions, and challenges. Bus. Horiz. 2018, 61, 35-46. [CrossRef]

11. Oh, D.-S.; Phillips, F.; Park, S.; Lee, E. Innovation Ecosystems: A Critical Examination. Technovation 2016, 54, 1-6. [CrossRef]

12. Chen, J.; Liu, X.; Hu, Y. Establishing a CoPs-based innovation ecosystem to enhance competence-the case of CGN in China. Int. J. Technol. Manag. 2016, 72, 144-170. [CrossRef]

13. Behnam, S.; Cagliano, R.; Grijalvo, M. How should firms reconcile their open innovation capabilities for incorporating external actors in innovations aimed at sustainable development? J. Clean. Prod. 2018, 170, 950-965. [CrossRef]

14. Moore, J.F. Predators and prey: a new ecology of competition. Harv. Bus. Rev. 1993, 71, 75-86.

15. Adner, R. Match your innovation strategy to your innovation ecosystem. Harv. Bus. Rev. 2006, 84, 98-107. [PubMed]

16. Gawer, A. Bridging differing perspectives on technological platforms: Toward an integrative framework. Res. Policy 2014, 43, 1239-1249. [CrossRef]

17. Adner, R. Rahul Kapoor Innovation ecosystems and the pace of substitution: re-examning technology S-curves. Strateg. Manag. J. 2016, 37, 625-648. [CrossRef]

18. Furr, N.; Shipilov, A. Building the Right Ecosystem for Innovation. MIT Sloan Manag. Rev. 2018, 59, 59-64.

19. Borgatti, S.P.; Foster, P.C. The network paradigm in organizational research: A review and typology. J. Manag. 2003, 29, 991-1013.

20. Hwang, V.W.; Horowitt, G. The Rainforest: The Secret to Building the Next Silicon Valley; Regenwald: Los Altos Hills, CA, USA, 2012; ISBN 9780615586724.

21. Wu, J.; Yang, Z.; Hu, X.; Wang, H.; Huang, J. Exploring driving forces of sustainable development of China's new energy vehicle industry: An analysis from the perspective of an innovation ecosystem. Sustainability 2018, 10, 4827. [CrossRef]

22. Hansen, M.T.; Birkinshaw, J. The innovation value chain. Harv. Bus. Rev. 2007, 85, 121-130.

23. Gawer, A.; Cusumano, M.A. Industry platforms and ecosystem innovation. J. Prod. Innov. Manag. 2014, 31, 417-433. [CrossRef] 
24. Hu, Y.; Zhang, S.; Li, J.; Sørensen, O.J. Gaining relational competitive advantages: A conceptual framework on rent generation and appropriation. Eur. J. Int. Manag. 2015, 9. [CrossRef]

25. Dyer, J.H.; Singh, H.; Hesterly, W.S. The relational view revisited: A dynamic perspective on value creation and value capture. Strateg. Manag. J. 2018, 39, 3140-3162. [CrossRef]

26. Adner, R.; Zemsky, P. A demand-based perspective on sustainable competitive advantage. Strateg. Manag. J. 2006, 27, 215-239. [CrossRef]

27. Walrave, B.; Talmar, M.; Podoynitsyna, K.S.; Romme, A.G.L.; Verbong, G.P.J. A multi-level perspective on innovation ecosystems for path-breaking innovation. Technol. Forecast. Soc. Chang. 2018, 136, 103-113. [CrossRef]

28. Dattée, B.; Alexy, O.; Autio, E. Maneuvering in poor visibility: How firms play the ecosystem game when uncertainty is high. Acad. Manag. J. 2018, 61, 466-498. [CrossRef]

29. Dhanaraj, C.; Parkhe, A. Orchestrating innovation networks. Acad. Manag. Rev. 2006, 31, 659-669. [CrossRef]

30. Iansiti, M.; Levien, R. Strategy as Ecology. Harv. Bus. Rev. 2004, 82, 1-10.

31. Valkokari, K.; Seppänen, M.; Mäntylä, M.; Jylhä-Ollila, S. Orchestrating Innovation Ecosystems: A Qualitative Analysis of Ecosystem Positioning Strategies. Technol. Innov. Manag. Rev. 2018, 7, 12-24. [CrossRef]

32. Hannah, D.P.; Eisenhardt, K.M. How firms navigate cooperation and competition in nascent ecosystems. Strateg. Manag. J. 2018, 39, 3163-3192. [CrossRef]

33. Hienerth, C.; Lettl, C.; Keinz, P. Synergies among producer firms, lead users, and user communities: The case of the LEGO producer-user ecosystem. J. Prod. Innov. Manag. 2014, 31, 848-866. [CrossRef]

34. Dedehayir, O.; Mäkinen, S.J.; Roland Ortt, J. Roles during innovation ecosystem genesis: A literature review. Technol. Forecast. Soc. Chang. 2016, 136, 18-29. [CrossRef]

35. Pitelis, C. Clusters, entrepreneurial ecosystem co-creation, and appropriability: A conceptual framework. Ind. Corp. Chang. 2012, 21, 1359-1388. [CrossRef]

36. Acs, Z.J.; Stam, E.; Audretsch, D.B.; O'Connor, A. The lineages of the entrepreneurial ecosystem approach. Small Bus. Econ. 2017, 49, 1-10. [CrossRef]

37. Hampshire, N. Value creation in innovation ecosystems: How the structure of technological interdependence affects firm performance in new technology generations. Strateg. Manag. J. 2010, 31, 306-333.

38. Williamson, P.J.; De Meyer, A. Ecosystem advantage: How to successfully harness the power of partners. Calif. Manag. Rev. 2012, 55, 24-46. [CrossRef]

39. de Vasconcelos Gomes, L.A.; Facin, A.L.F.; Salerno, M.S.; Ikenami, R.K. Unpacking the innovation ecosystem construct: Evolution, gaps and trends. Technol. Forecast. Soc. Chang. 2018, 136, 30-48. [CrossRef]

40. Le Roy, F.; Czakon, W. Managing coopetition: The missing link between strategy and performance. Ind. Mark. Manag. 2016, 53. [CrossRef]

41. Hoffmann, W.; Lavie, D.; Reuer, J.J.; Shipilov, A. The interplay of competition and cooperation. Strateg. Manag. J. 2018, 39, 3033-3052. [CrossRef]

42. Park, B.J.R.; Srivastava, M.K.; Gnyawali, D.R. Walking the tight rope of coopetition: impact of competition and cooperation intensities and balance on firm innovation performance. Ind. Mark. Manag. 2014, 43, 210-221. [CrossRef]

43. Das, T.K.; Teng, B.-S. Instabilities of Strategic Alliances: An Internal Tensions Perspective. Organ. Sci. 2000, 11, 77-101. [CrossRef]

44. Ranganathan, R.; Ghosh, A.; Rosenkopf, L. Competition-cooperation interplay during multifirm technology coordination: The effect of firm heterogeneity on conflict and consensus in a technology standards organization. Strateg. Manag. J. 2018, 39. [CrossRef]

45. Kapoor, R.; Lee, J.M. Coordinating and competing in ecosystems: How organizaitonal forms shape new technology investments. Strateg. Manag. J. 2013, 34, 274-296. [CrossRef]

46. Chesbrough, H. The era of open innovation. MIT Sloan Manag. Rev. 2003, 44, 26-32.

47. Leten, B.; Vanhaverbeke, W.; Roijakkers, N.; Clerix, A.; Van Helleputte, J. IP models to orchestrate innovation ecosystems. Calif. Manag. Rev. 2013, 55, 51-64. [CrossRef]

48. Eisenhardt, K.M.; Graebner, M.E. Theory Building from Cases: Opportunities and Challenges. Organ. Res. Methods 2007, 50, 25-32. [CrossRef]

49. Glaser, B.; Strauss, A. Discovery of Grounded Theory: Strategies for Qualitative Research; Routledge: Abingdon, $\mathrm{UK}, 2017$. 
50. Yin, R. Case Study Research and Applications: Design and Methods; Sage Publications: Thousand Oaks, CA, USA, 2017.

51. Prajogo, D.I.; Ahmed, P.K. Relationships between innovation stimulus, innovation capacity, and innovation performance. R D Manag. 2006, 36, 499-515.

52. Armbruster, H.; Bikfalvi, A.; Kinkel, S.; Lay, G. Organizational innovation: The challenge of measuring non-technical innovation in large-scale surveys. Technovation 2008, 28, 644-657. [CrossRef] 